Torrecilla Patiño, Elia; Molina Alarcón, Miguel.

Laboratorio de Creaciones Intermedia, Departamento de Escultura,

Universitat Politècnica de València.

\title{
Performances mínimas en el espacio urbano y colaboraciones a distancia. Propuestas de "Acciones Desapercibidas" como experiencia entre lo local y lo translocal.
}

\section{Minimum performances in the urban space and distance collaborations. Proposals for "Unnoticed Actions" as an experience between the local and the translocal.}

TIPO DE TRABAJO:

Comunicación.

PALABRAS CLAVE:

Performance, cuerpo, espacio, ciudad, tecnología.

KEY WORDS:

Performance, body, space, city, technology.

RESUMEN

En la presente comunicación mostramos la experiencia obtenida de la participación en un proyecto internacional y su puesta en acción en el ámbito local.

Partiendo de la investigación sobre cuestiones que abordan la relación entre cuerpo, ciudad y tecnología, comenzamos a experimentar en el espacio urbano la práctica de una serie de performances mínimas inscritas en el ámbito de lo cotidiano.

Tras el descubrimiento de una propuesta desarrollada en Holanda, profundizamos en el uso de la ciudad como laboratorio y escenario donde llevar a cabo nuestras Acciones Desapercibidas; así comenzamos una serie de colaboraciones con los organizadores del Unnoticed Art Festival, empleando, en ocasiones, el uso de dispositivos móviles. Este es el caso de Parallel Walks, una serie de paseos paralelos simultáneos en los que deambulamos siguiendo las directrices que nos enviamos, de una ciudad a otra a través de mensajería instantánea, creando un recorrido en una tercera ciudad resultante de ambas.

De este modo, las prácticas artísticas colectivas se vuelven más accesibles y nos permiten experimentar nuevas posibilidades que incluyen las colaboraciones a distancia, la translocalización, la simultaneidad y la posibilidad de realizar acciones y desplazarnos por una ciudad híbrida. 


\section{Torrecilla Patiño, Elia; Molina Alarcón, Miguel \\ Performances mínimas en el espacio urbano y colaboraciones a distancia. \\ Propuestas de "Acciones Desapercibidas" como experiencia entre lo local y lo translocal \\ III CONGRESO INTERNACIONAL DE INVESTIGACIÓN EN ARTES VISUALES :: ANIAV 2017 :: GLOCAL [codificar, mediar, transformar, vivir] \\ http://dx.doi.org/10.4995/ANIAV.2017.4899}

Finalmente, llevamos esta experiencia al ámbito de la docencia realizando acciones mínimas en el espacio urbano de Valencia, con propuestas creadas por los propios estudiantes, junto a otras que restituían algunos referentes de arte de acción del periodo de la vanguardia histórica española. Esta parte de recuperación histórica, se realizó con el fin de utilizar el cuerpo como generador de historia desde la investigación-acción y comprobar si su recepción actual sería la misma o no, así como jugar y producir nuevas relecturas entre presente-pasado, local-global, creador-receptor, ArteNoArte o cotidianidad-sorpresa. Estos resultados forman parte de un proyecto I+D concedido por el Ministerio de Economía y Competitividad (ref. HAR2014-58869-P).

\section{ABSTRACT.}

In this communication we show the experience gained from participating in an international project and its implementation at the local level.

Starting from research on issues that address the relationship between body, city and technology, we begin to experience in the urban space the practice of a series of minimum performances inscribed in the realm of everyday life.

After the discovery of a proposal developed in Holland, we deepen the use of the city as a laboratory and stage where we carry out our Unapproved Actions; So we began a series of collaborations with the organizers of the Unnoticed Art Festival, sometimes using the use of mobile devices. This is the case of Parallel Walks, a series of simultaneous parallel walks in which we wandered following the guidelines we send, from one city to another through instant messaging, creating a tour in a third city resulting from both.

In this way, collective artistic practices become more accessible and allow us to experience new possibilities that include distance collaborations, translocation, simultaneity and the possibility of performing actions and moving through a hybrid city.

Finally, we bring this experience to the field of teaching by performing minimal actions in the urban space of Valencia, with proposals created by the students themselves, along with others that restored some references of action art from the period of the Spanish historical avant-garde. This part of historical recovery was done in order to use the body as a generator of history from action research and check whether its current reception would be the same or not, as well as play and produce new re-readings between present-past, local- Global, creator-receiver, Arte-NoArte or everydaysurprise. These results are part of an R \& D project awarded by the Ministry of Economy and Competitiveness (ref HAR2014-58869-P). 